JSIP: Jurnal Studi Ilmu Pemerintahan

Volume 2, No 1 Februari 2021

ISSN: 2722-7405

\title{
PERAN SANIRI NEGERI DALAM MENYALURKAN ASPIRASI MASYARAKAT TERHADAP PENYUSUNAN PROGRAM PEMBANGUNAN NEGERI TIAL KABUPATEN MALUKU TENGAH
}

\author{
Farah Lessy ${ }^{1}$ \\ Wahab Tuanaya ${ }^{2}$ \\ Marno Wance ${ }^{3}$ \\ ${ }^{1}$ Mahasiswa Ilmu Pemerintahan, Universitas Pattimura, Indonesia \\ 2,3Dosen Ilmu Pemerintahan, Universitas Pattimura, Indonesia \\ ipmummu@gmail.com
}

\begin{abstract}
Article Info
Keyword:

Saniri institutions 1;

Development

program 2;

Negeri planning 3.

Kata Kunci:

Lembaga saniri 1;

Program

pembangunan 2;

Perencanaan negeri 3.

Abstract: research was conducted to figure out the role of Saniri, institution in a village, in conducting programs of development planning at the village with custom status (Negeri). The limited experience and the lack of education possessed by traditional institution members (Saniri) were the initial reason that led the researchers to conduct this in-depth research. The following reason was that Saniri has a joint planning function with the head of the village called Kepala Raja. This study used a quantitative approach by dividing the samples into 17 government and Saniri institutions and 80 public communities. The result reveals that the calculation of the product moment correlation shows a positive relationship and influence between the two variables. This result means that the role of Saniri Negeri in channeling community aspirations has a positive role in influencing the preparation of development programs in Negeri Tial, Salahutu District, Central Maluku Regency.
\end{abstract}

\begin{abstract}
Abstrak: Penelitian yang dilakukan untuk mengetahui peran lembaga saniri dalam melakukan penyusunan program pembangunan pada perencanaan pembangunan di desa yang berstatus negeri/adat. Keterbatasa npengalaman dan minimnya pendidikan yang dimiliki oleh lembaga adat (Saniri) sehingga peneliti melakukan riset secara mendalam pada lembaga saniri yang memiliki fungsi perencanaan bersama dengan kepala raja. Penelitian ini menggunakan pendekatan kuantitatif dengan membagi sampel pada pemerintah negeri dan lembaga saniri sebanyak 17 dan masyarakat negeri sebanyak 80 sample. Hasil perhitungan korelasi product moment menunjukan adanya hubungan dan pengaruh yang positif antara kedua variable tersebut artinya bahwa peran saniri negeri dalam penyaluran aspirasi masyarakat memiliki peran positif dalam mempengaruhi penyusunan program pembangunan di Negeri Tial Kecamatan Salahutu Kabupaten Maluku Tengah.
\end{abstract}

\section{Pengantar}

Desa bagi daerah Maluku, khususnya Maluku Tengah dan Pulau Ambon lazimnya disebut "Negeri", yang didalamnya termasuk Pemerintah Negeri. Negeri adalah kesatuan masyarakat hukum adat yang bersifat geneologis teritorial yang memiliki batas wilayah, berwenang mengatur dan mengurus kepentingan masyarakatnya berdasarkan hak asal usul dan adat istiadat setempat. Peraturan daerah provinsi Maluku nomor 14 tahun 2005 tentang penetapan kembali "negeri" sebagai kesatuan masyarakat hukum adat dalam willayah pemerintahan provinsi maluku. Dengan diberlakukannya Undang Undang No 32 Tahun 2004, maka lembagalembaga adat seperti Saniri memiliki pengakuan terhadap eksistensinya yang terlegitimasi 
dengan nama Badan Saniri Negeri. pada awalnya pemerintah dan masyarakat konsisten dalam menerapkan ketentuan adat dalam pemilihan raja namun, saat ini masyarakat mengalami perubahan pemikiran dalam hal ketentuan adat mengenai pemilihan raja (Touwe, Tuanaya, Wance, 2020)

Saniri negeri adalah sebuah lembaga legislatif yang berada di suatu negeri/desa. Hal tersebut memiliki kekuatan hukum yang bersumber pada peraturan daerah kabupaten maluku tengah nomor 04 tahun 2006 tentang pedoman penataan badan saniri negeri. Keberadaan badan saniri negeri diharapkan dapat membawa pembaharuan dalam penyelenggaraan pemerintahan dan pelaksanaan pembangunan di negeri. Sebagai badan perwakilan yang terdiri atas pemukapemuka masyarakat yang ada di negeri, badan saniri negeri mempunyai fungsi yaitu menampung dan menyalurkan aspirasi masyarakat negeri.

Badan saniri negeri berperan untuk menyerap dan menyalurkan berbagai aspirasi masyarakat serta memperjuangkan agar bisa terwujud dalam kebijakan pemerintah negeri. Anggota badan saniri negeri dianggap sebagai representasi masyarakat luas sehingga harus mampu mewakili aspirasi yang berkembang di tengah-tengah masyarakat. Sebagai suatu lembaga di negeri yang tumbuh dari internal wilayah untuk mengumpulkan berbagai keinginan dan harapan masyarakat sehingga menjadi wadah bagi setiap partisipasi masyarakat dalam pembangunan guna memadukan pelaksanaan berbagai kegiatan pembangunan negeri.

Menurut Eisinger dalam Pito (2006 : 111), menyatakan bahwa "pemahaman mengenai sistem perwakilan tentunya memberikan gambaran bahwa perwakilan indivdu harus memahami aspirasi, nilai kepercayaan dan sikap-sikap masyarakat". Oleh karena itu menurutnya sistem perwakilan harus mewujudkan fungsinya secara nyata dalam penyelenggaraan kehidupan bermasyarakat dan bernegara. Paradigrama baru administrasi public muncul dengan merumuskan sejumlah kebijakan pembangunanan (Herizal, Mukhrijal, Wance, 2020)

Pelaksanaan kegiatan pembagunan di sebuah desa ataupun negeri merupakan perpaduan antara pemerintah dengan masyarakat yang di dalamnya terdapat lembaga-lembaga pemerintahan adat seperti saniri negeri yang merupakan elemen masyarakat adat yang memegang peranan penting dalam menunjang keberhasilan pembangunan di negeri tersebut. Pembangunan memang perlu adanya perlu partisipasi masyarakat dan memang perlu di kembangkan intensinya pengertian umum yang dapat disimak dari istilah partisipasi adalah keikutsertaan suatu kelompok masyarakat dalam program pembangunan itu sebabnya partisipasi sebagai satu prinsip atau konsep resmi. (M. Dawan Rahardjo, 2010).

Di Maluku Desa/Negeri dikepalai oleh seorang Raja (Kepala Pemerintahan Negeri), Raja dibantu oleh Badan Saniri Negeri. Berdasarkan Peraturan Daerah Kabupaten Maluku Tengah No. 04 tahun 2006 tentang Pedoman Penataan Badan Saniri Negeri, disebutkan bahwa: "Saniri Negeri adalah lembaga atau badan yang merupakan perwujudan demokrasi dalam penyelenggaraan Pemerintah Negeri, berfungsi sebagai badan legislatif yang bersama-sama Kepala Pemerintahan Negeri (Raja) membentuk peraturan negeri, megawasi pelaksanaan tugas dari Kepala Pemerintah Negeri serta merupakan badan yang mendampingi Kepala Pemerintahan Negeri dalam memimpin negeri, sesuai tugas dan wewenang yang dimilikinya". Hasil penelitian yang dilakukan oleh Wance (2017) interaksi antara lembaga eksekutif dan legislatif dalam perencanaan anggaran selalu ditemukan pertentangan kepentingan (Wance, 2017).

Badan Saniri Negeri di Negeri Tial pada saat ini tidak berfungsi optimal dalam perannya menyalurkan aspirasi masyarakat terhadap penyusunan program pembangunan. Kondisi ini dapat dilihat dari tingkat pertemuan Badan Saniri Negeri dengan masyarakat yang rendah menyebabkan penyusunan program kerja Negeri yang tidak responsif sesuai dengan keinginan dan aspirasi masyarakat. Saat ini pun, kondisi pemerintahan adat negeri dipimpin oleh seorang 
pejabat yang diutus oleh pemerintah diatasnya akibat kekosongan posisi raja yang berkedudukan sebagai kepala pemerintahan negeri menyebabkan pemerintah diatasnya lebih dominan dalam pengambilan keputusan sehingga saniri negeri kurang berperan baik dalam menyalurkan aspirasi masyarakat maupun pengawasan dikarenakan semua dikontrol langsung oleh pemerintah diatasnya.

Masyarakat menilai bahwa Badan Saniri yang terbentuk selama ini bukan murni melalui suatu mekanisme adat tetapi merupakan penunjukan terhadap orang-orang terdekat dengan pejabat desa yang ada sehingga menyebabkan masyarakat merasa jenuh dalam menyampaikan aspirasinya karena mereka menganggap keputusan terakhir hanya berada di bapak pejabat dan para pemangku kepentingan yang dipilih olehnya. Begitu pula berkaitan dengan penyusunan program-program pembangunan yang seharusnya sesuai dengan kebutuhan masyarakat atau dengan memperhatikan dan memahami aspirasi masyarakat yang berkembang, bukan karena merupakan keinginan dari beberapa orang tertentu, seperti tokoh-tokoh masyarakat atau pejabat kepala desa bersama kelompoknya yang mempunyai kewenangan menentukan keputusan dalam penetapan program pembangunan yang ada di desa ini.

Tujuan penyaluran dana sosial melalui Dana Desa (DD) untuk memulihkan keadaan ekonomi masyarakat serta peran kelompok-kelompok masyarakat untuk mengawal proses pelaksanaan program bantuan sosial yang dilakukan oleh pemerintah desa. (Tuanaya, Tuhumury, Wance, 2020)

Dari penjelasan di atas, kiranya dapat dijelaskan beberapa indikasi yang menyebabkan belum optimalnya peran saniri dalam menyalurkan aspirasi masyarakat terhadap penyusunan program pembangunan di Negeri Tial, diantaranya adalah :

1. Kurang berperannya saniri negeri dalam mengadakan rapat atau pertemuan bersama anggota masyarakat dalam rangka menjaring aspirasi masyarakat, sehingga berimplikasi pada kurang maksimalnya peran saniri negeri dalam menyalurkan aspirasi masyarakat pada kegiatan Musrenbang yang diikuti saniri.

2. Belum jelas mekanisme penghimpunan dan penyaluran aspirasi masyarakat terkait penyampaian ide atau gagasan-gagasan pembangunan yang sesuai dengan kebutuhan masyarakat.

3. Pemerintah negeri memiliki kewenangan lebih dalam penentuan rencana pembangunan negeri sehingga aspirasi masyarakat kurang tersalurkan walaupun telah disampaikan oleh anggota saniri dalam rapat penyelarasan program pembangunan desa.

\section{METODE PENELITIAN}

Bagian ini berisi desain penelitian, subjek / objek / sampel penelitian, definisi operasional dan variabel pengukuran, teknik pengumpulan data / instrumen dan analisis data serta pengujian hipotesis. Jika penulis ingin merepresentasikan gambar / tabel dalam ukuran besar, maka gambar / tabel tersebut dapat disajikan dalam satu kolom.

Penelitian ini merupakan penelitian yang bertujuan menjelaskan fenomena yang ada secara statistik korelasional dengan menggunakan angka-angka untuk mencandarkan karakteristik individu atau kelompok (Syamsudin \& Damiyanti: 2011). Penelitian ini menilai sifat dari kondisi-kondisi yang tampak. Berdasarkan tujuan penelitian yang ada maka yang menjadi populasi dalam penelitian ini meliputi seluruh aparatur Pemerintah Negeri Tial (Kepala Pemerintahan Negeri bersama perangkat Negeri dan Anggota Saniri) yang berjumlah 16 orang, serta ditambah dengan seluruh anggota masyarakat desa yang berada dalam lingkungan pemerintah Negeri Tial dan ditarik dari unsur kepala keluarga. 
Untuk itu dalam penelitian ini, sampel yang akan ditarik dengan kategorisasi berdasarkan jenis populasinya, antara lain sebagai berikut;

a) Sampel dari elemen Pemerintah Desa akan digunakan teknik sensus dimana seluruh populasi yang ada, langsung ditetapkan sebagai sampel penelitian, yang terdiri dari ;

1. Kepala Pemerintahan Negeri 1 orang

2. Sekretaris Negeri 1 orang

3. Kepala Urusan sebanyak 3 orang

4. Kepala seksi sebanyak 1 orang

5. Anggota Saniri sebanyak 16 orang

Atas dasar itu maka jumlah sampel penelitian dari unsur aparat dan perangkat pemerintah Negeri yang berjumlah 17 orang,

b) Dari unsur masyarakat Negeri Tial, akan ditarik dengan menggunakan teknik random sampling dengan besaran rata-rata $10 \%$ dari Jumlah kepala keluarga sebanyak 802 orang, dan dari hasil penarikannya dapat diperoleh sebanyak 80 orang.

Berdasarkan jumlah sampel penelitian seperti digambarkan di atas dari unsur masyarakat negeri, semuanya berjumlah 80 orang KK. Dengan demikian, jumlah sampel secara keseluruhan dalam penelitian ini berjumlah 82 orang.

Relevansinya dengan permasalahan pokok yang diajukan dalam penelitian ini serta hipotesis yang diajukan sebagai jawaban sementara dalam menjawab permasalahan tersebut maka untuk menganalisa data guna menguji hipotesis yang ada akan digunakan Teknik analisis secara statistik dengan menggunakan rumus Korelasi Produc Moment (Effendi dan Singarimbun, (1989) yang formulasinya sebagai berikut :

$$
r_{x y}=\frac{N\left(\sum X Y\right)-\left(\sum X\right)\left(\sum Y\right)}{\sqrt{\left\{N\left(\sum X^{2}\right)-\left(\sum X\right)^{2}\right\}\left\{N\left(\sum Y^{2}\right)-\left(\sum Y\right)^{2}\right\}}}
$$

Dimana :

$\mathrm{r}_{\mathrm{xy}}=$ Koofisien Korelasi

$\mathrm{X}=$ Skor dalam distribusi variable $\mathrm{X}$

$\mathrm{Y}=$ Skor dalam distribusi variable $\mathrm{Y}$

$\mathrm{N} \quad=$ Banyaknya subjek.

Sedangkan untuk mengetahui apakah hubungan antara kedua variabel pokok yaitu variabel peran saniri dalam penyaluran aspirasi masyarakat (Variabel X) dengan Variabel penyusunan program pembangunan (Variabel Y) memiliki hubungan yang signifikan atau tidak, maka akan dilakukan melalui uji signifikansi dengan cara membandingkan atau mengkonsultasikan nilai $r$ hitung dengan nilai $r$ tabel pada taraf kepercayaan $95 \%$ atau pada tingkat signifikan $0,5 \%$ dengan degree of fredom $(\mathrm{Df}=\mathrm{N}-2)$.

\section{HASIL DAN DISKUSI}

Berdasarkan pedoman analisis data, selanjutnya dikemukakan analisis data dan interpretasi data terhadap data yang diperoleh dari hasil penelitian di lapangan yang berhubungan dengan kedua variabel pokok penelitian. Data tersebut diperoleh dari kuisioner yang diberikan kepada setiap responden. Untuk itu sebelum variabel-variabel penelitian dihitung berdasarkan rumus korelasi product moment, akan dipaparkan lebih dahulu data variabel $\mathrm{x}$ (peran saniri negeri dalam penyaluran aspirasi masyarakat) dan data variabel y (penyusunan program pembangunan) seperti terlihat pada pada tabel sebagai berikut :

Tanggapan Responden Terhadap Variabel X (Peran Saniri Negeri Dalam Penyaluran Aspirasi Masyarakat) 


\begin{tabular}{|c|c|c|c|c|c|c|}
\hline \multirow{3}{*}{$\begin{array}{l}\text { No } \\
1\end{array}$} & \multirow{2}{*}{ Indikator } & \multirow{2}{*}{ Pertanyaan } & \multirow{2}{*}{$\begin{array}{c}\text { Variabel } \\
\text { jawaban }\end{array}$} & \multicolumn{2}{|c|}{ Jumlah } & \multirow{2}{*}{ Ket. } \\
\hline & & & & $\mathrm{F}$ & $\%$ & \\
\hline & $\begin{array}{lr}\text { Pelaksanaan } & \text { rapat } \\
\text { saniri } & \text { dengan } \\
\text { masyarakat } & \end{array}$ & $\begin{array}{lr}\text { Apakah } & \text { saniri } \\
\text { mengadakan } & \text { rapat } \\
\text { dengan masyarakat guna } \\
\text { membahas program } \\
\text { pembangunan? }\end{array}$ & $\begin{array}{l}\text { a. ada } \\
\text { b. kurang } \\
\text { c.tidak } \\
\text { pernah }\end{array}$ & $\begin{array}{l}41 \\
27 \\
14\end{array}$ & $\begin{array}{l}50 \\
33 \\
17\end{array}$ & \multirow{4}{*}{$\begin{array}{l}\mathrm{N} \\
82\end{array}$} \\
\hline 2 & $\begin{array}{l}\text { Adanya kesempatan } \\
\text { untuk } \\
\text { menyampaikan ide } \\
\text { / gagasan }\end{array}$ & $\begin{array}{l}\text { Apakah masyarakat } \\
\text { diberikan kesempatan } \\
\text { untuk menyampaikan ide } \\
\text { atau gagasan dalam } \\
\text { rapat? }\end{array}$ & $\begin{array}{l}\text { a. ada } \\
\text { b. kurang } \\
\text { c.tidak } \\
\text { pernah }\end{array}$ & $\begin{array}{l}35 \\
31 \\
16\end{array}$ & $\begin{array}{l}43 \\
38 \\
19\end{array}$ & \\
\hline 3 & $\begin{array}{lr}\text { Kualitas } & \text { saniri } \\
\text { dalam } & \text { menyerap } \\
\text { aspirasi masyarakat }\end{array}$ & $\begin{array}{l}\text { Apakah dalam rapat ide } \\
\text { yang disampaikan } \\
\text { pernah ditolak? }\end{array}$ & $\begin{array}{l}\text { a. ada } \\
\text { b. kurang } \\
\text { c.tidak } \\
\text { pernah }\end{array}$ & $\begin{array}{l}40 \\
17 \\
25\end{array}$ & $\begin{array}{l}49 \\
21 \\
30\end{array}$ & \\
\hline 4 & $\begin{array}{l}\text { Kemampuan saniri } \\
\text { dalam menyalurkan } \\
\text { aspirasi masyarakat }\end{array}$ & $\begin{array}{lr}\text { Apakah ide } & \text { masyarakat } \\
\text { tertampung } & \text { dan } \\
\text { disalurkan } & \text { dalam } \\
\text { penyusunan } & \text { program } \\
\text { pembangunan? } & \end{array}$ & $\begin{array}{l}\text { a. ada } \\
\text { b. kurang } \\
\text { c.tidak } \\
\text { pernah }\end{array}$ & $\begin{array}{l}36 \\
24 \\
22\end{array}$ & $\begin{array}{l}44 \\
29 \\
27\end{array}$ & \\
\hline
\end{tabular}

Tabel 8. Tanggapan Responden Terhadap Variabel $X$

Berdasarkan tabel diatas dapat dikatakan bahwa responden yang mengatakan saniri mengadakan rapat dengan masyarakat guna membahas program pembangunan sebanyak 41 orang (50\%), yang mengatakan saniri kurang mengadakan rapat dengan masyarakat guna membahas program pembangunan sebanyak 27 orang (33\%), sedangkan sebanyak 14 orang (17\%) mengatakan saniri tidak pernah mengadakan rapat dengan masyarakat guna membahas program pembangunan.

Selanjutnya sebanyak 35 orang (43\%) yang mengatakan masyarakat diberikan kesempatan untuk menyampaikan ide dalam rapat, sebanyak 31 orang (38\%) mengatakan masyarakat kurang diberikan kesempatan untuk menyampaikan ide dalam rapat, dan sebanyak 16 orang (19\%) mengatakan masyarakat tidak pernah diberikan kesempatan untuk menyampaikan ide dalam rapat.

Sedangkan sebanyak 40 orang (49\%) yang mengatakan dalam rapat ide yang disampaikan pernah ditolak, sebanyak 17 orang (21\%) mengatakan dalam rapat ide yang disampaikan kurang ditolak, dan mengatakan dalam rapat ide yang disampaikan tidak pernah ditolak sebanyak 25 orang (30\%).

Dan yang mengatakan ide masyarakat tertampung dan disalurkan dalam penyusunan program pembangunan adalah sebanyak 36 orang (44\%), yang mengatakan ide masyarakat kurang tertampung dan disalurkan dalam penyusunan program pembangunan sebanyak 24 orang (39\%), dan sebanyak 22 orang (27\%) yang mengatakan ide masyarakat tidak pernah tertampung dan disalurkan dalam penyusunan program pembangunan.

\section{Tanggapan Responden Terhadap Variabel Y (Penyusunan Program Pembangunan)}

\begin{tabular}{|l|l|l|l|l|l|l|}
\hline \multirow{2}{*}{ No } & \multirow{2}{*}{ Indikator } & \multirow{2}{*}{ Pertanyaan } & \multirow{2}{*}{$\begin{array}{l}\text { Variabel } \\
\text { jawaban }\end{array}$} & \multicolumn{2}{|c|}{ Jumlah } & \multirow{2}{*}{ Ket. } \\
& & & & & \\
\end{tabular}




\begin{tabular}{|c|c|c|c|c|c|c|}
\hline 1 & $\begin{array}{lr}\text { Pemerintah } & \text { negeri } \\
\text { menerima } & \text { usulan } \\
\text { program } & \\
\text { pembangunan } & \text { dari } \\
\text { masyarakat } & \end{array}$ & $\begin{array}{l}\text { Apakah pemerintah } \\
\text { menerima ide yang } \\
\text { telah ditampung oleh } \\
\text { saniri dalam } \\
\text { penyusunan } \\
\text { pembuatan program? }\end{array}$ & $\begin{array}{l}\text { a. ada } \\
\text { b. kurang } \\
\text { c.tidak } \\
\text { pernah }\end{array}$ & $\begin{array}{l}47 \\
28 \\
7\end{array}$ & $\begin{array}{l}57 \\
34 \\
9\end{array}$ & \\
\hline 2 & $\begin{array}{lr}\text { Konsistensi } & \\
\text { pemerintah } & \text { negeri } \\
\text { dalam } & \text { rapat } \\
\text { penyusunan } & \text { rencana } \\
\text { pembangunan negeri }\end{array}$ & $\begin{array}{lr}\text { Apakah } & \text { pemerintah } \\
\text { mengambil } & \text { keputusan } \\
\text { dalam } & \text { program } \\
\text { pembangunan } & \text { desa } \\
\text { sesuai dengan aspirasi } \\
\text { masyarakat } \\
\text { ditampung oleh } & \text { saniri } \\
\text { negeri? }\end{array}$ & $\begin{array}{l}\text { a. ada } \\
\text { b. kurang } \\
\text { c.tidak } \\
\text { pernah }\end{array}$ & $\begin{array}{l}52 \\
18 \\
12\end{array}$ & $\begin{array}{l}63 \\
22 \\
15\end{array}$ & $\begin{array}{l}\mathrm{N}= \\
82\end{array}$ \\
\hline 3 & $\begin{array}{l}\text { Kemampuan } \\
\text { pemerintah negeri } \\
\text { dalam melaksanakan } \\
\text { pembangunan susuai } \\
\text { aspirasi masyarakat }\end{array}$ & $\begin{array}{l}\text { Dalam pelaksanaan } \\
\text { pembangunan apakah } \\
\text { sesuai dengan aspirasi } \\
\text { masyarakat yang telah } \\
\text { disampaikan dan } \\
\text { ditampung oleh saniri } \\
\text { negeri? }\end{array}$ & $\begin{array}{l}\text { a. ada } \\
\text { b. kurang } \\
\text { c.tidak } \\
\text { pernah }\end{array}$ & $\begin{array}{l}48 \\
22 \\
12\end{array}$ & $\begin{array}{l}58 \\
27 \\
15\end{array}$ & \\
\hline 4 & $\begin{array}{l}\text { Kepuasan masyarakat } \\
\text { atas } \\
\text { pelaksanakan } \\
\text { pembangunan }\end{array}$ & $\begin{array}{l}\text { Apakah ada kepuasan } \\
\text { dari masyarakat atas } \\
\text { hasil pelaksanaan } \\
\text { pembangunan di } \\
\text { negeri? }\end{array}$ & $\begin{array}{l}\text { a. ada } \\
\text { b. kurang } \\
\text { c.tidak } \\
\text { pernah }\end{array}$ & $\begin{array}{l}49 \\
19 \\
14\end{array}$ & $\begin{array}{l}60 \\
23 \\
17\end{array}$ & \\
\hline
\end{tabular}

\section{Tabel 9. Tanggapan Responden Terhadap Variabel Y}

Gambaran tabel di atas menunjukan bahwa 47 orang responden (57\%) mengatakan pemerintah menerima ide yang telah ditampung oleh saniri dalam penyusunan program pembangunan, sebanyak 28 orang (34\%) mengatakan pemerintah kurang menerima ide yang telah ditampung oleh saniri dalam penyusunan program pembangunan, dan 7 orang (9\%) mengatakan pemerintah tidak pernah menerima ide yang telah ditampung oleh saniri dalam penyusunan program pembangunan.

Kemudian yang mengatakan pemerintah mengambil keputusan dalam program pembangunan desa sesuai dengan aspirasi masyarakat yang ditampung oleh saniri negeri sebanyak 52 orang (63\%), yang mengatakan pemerintah kurang mengambil keputusan dalam program pembangunan desa sesuai dengan aspirasi masyarakat yang ditampung oleh saniri negeri sebanyak 18 orang (22\%), dan 12 orang (15\%) yang mengatakan pemerintah tidak pernah mengambil keputusan dalam program pembangunan desa sesuai dengan aspirasi masyarakat yang ditampung oleh saniri negeri.

Sedangkan sebanyak 48 orang (58\%) yang mengatakan dalam pelaksanaan pembangunan sesuai dengan aspirasi masyarakat yang telah disampaikan dan ditampung oleh saniri negeri, sebanyak 22 orang (27\%) yang mengatakan dalam pelaksanaan pembangunan kurang sesuai dengan aspirasi masyarakat yang telah disampaikan dan ditampung oleh saniri negeri, dan sebanyak 12 orang (15\%) yang mengatakan dalam pelaksanaan pembangunan tidak pernah sesuai dengan aspirasi masyarakat yang telah disampaikan dan ditampung oleh saniri negeri. 
Selanjutnya sebanyak 49 orang (60\%) mengatakan ada kepuasan dari masyarakat atas hasil pelaksanaan pembangunan di negeri, yang mengatakan kurang kepuasan dari masyarakat atas hasil pelaksanaan pembangunan di negeri sebanyak 19 orang (23\%), dan mengatakan tidak ada kepuasan dari masyarakat atas hasil pelaksanaan pembangunan di negeri adalah sebanyak 14 orang (17\%).

\section{KESIMPULAN}

Penelitian ini adalah penelitian kuantitatif yang mengkaji hubungan dan pengaruh antara Variabel X yaitu Peran Saniri Negeri dalam Penyaluran Aspirasi Masyarakat terhadap Variabel Y yaitu Penyusunan Program Pembangunan di Negeri Tial Kecamatan Salahutu Kabupaten Maluku Tengah. Berdasarkan hasil analisis data yang telah penulis kemukakan dengan memperhatikan data dari hasil penelitian, maka dapatlah dibuat kesimpulan dari hasil perhitungan korelasi product moment menunjukan adanya hubungan dan pengaruh yang positif antara kedua variabel tersebut artinya bahwa peran saniri negeri dalam penyaluran aspirasi masyarakat memiliki peran positif dalam mempengaruhi penyusunan program pembangunan di Negeri Tial Kecamatan Salahutu Kabupaten Maluku Tengah.

Hal ini dibuktikan dengan nilai korelasi dari hasil perhitungan sebesar 0,55 yang kemudian dilakukan pengujian dengan menggunakan rumus T-test dan hasil pengujian T-test lebih besar dari T-tabel $(5,89>0,55)$. Dengan demikian hipotesis yang menyatakan ada hubungan yang signifikan antara peran saniri negeri dalam penyaluran aspirasi masyarakat terhadap penyusunan program pembangunan di Negeri Tial Kecamatan Salahutu Kabupaten Maluku Tengah diterima daya keberlakuannya

\section{PENGAKUAN}

Terima kasih kepada dosen dan Prodi Ilmu Pemerintahan, FISIP, Universitas Pattimura yang telah memberikan motivasi dan masukan sehingga penelitian ini bisa dilakukan sampai selesai.

\section{DAFTAR PUSTAKA}

Pito, Toni Andrianus, Efrizah, dan Kamal Fasyah, 2006, Mengenal Teori-Teori Politik, dari

Sistem Politik Sampai Korupsi, Bandung: Nuansa.

Rahardjo, M. Dawam. 2010. Intelektual, Intelegasi, dan Perilaku Politik dan Bangsa. Bandung:

Mizan.

Singarimbun, M., \& Effendi, S. (1989). Metodologi penelitian survei. Jakarta: LP3ES.

Syamsudin \& Damiyanti: 2011, Penelitian deskriptif,

Touwe, M. A., Tuanaya, W., \& Wance, M. (2020). Sistem Pemilihan Raja Negeri Munarten

Kecamatan Taniwel Kabupaten Seram Bagian Barat. Jurnal Studi Ilmu Pemerintahan, 1(2), 115.

Tuanaya, W., Tuhumury, J. J., \& Wance, M. (2020). MANAGEMENT MODEL AND VILLAGE FUND ALLOCATION DURING PANDEMIC COVID-19 IN WAIHERU VILLAGE AMBON

CITYINDONESIA. PalArch's Journal of Archaeology of Egypt/Egyptology, 17(7), 13357-13369.

Herizal, H., Mukhrijal, M., \& Wance, M. (2020). Pendekatan Akuntabilitas Pelayanan Publik

Dalam Mengikuti Perubahan Paradigma Baru Administrasi Publik. Journal of Governance and Social Policy, 1(1). 
Wance, M. (2017). POLITIK ANGGARAN EKSEKUTIF DAN LEGISLATIF PADA PEMBAHASAN APBD KABUPATEN BURU SELATAN 2015. JOURNAL OF GOVERNMENT (Kajian Manajemen Pemerintahan dan Otonomi Daerah), 2(2), 178-204. 